\begin{tabular}{|c|c|c|}
\hline Beitr. Ent. & Keltern & ISSN 0005-805X \\
\hline $\mathbf{5 8}(2008) 1$ & S. $107-112$ & 15.07 .2008 \\
\hline
\end{tabular}

\title{
Nesting behaviour and notes on mimetic relationships of Hoplisoides vespoides (SMITH) from Brazil
}

\section{(Hymenoptera: Crabronidae)}

With 2 figures and 2 tables

SANDOr Christiano Buys

\section{Summary}

The nesting behaviour of Hoplisoides vespoides (SMITH, 1873) is described based on observations carried out in southeastern Brazil. Notes on mimetic relationships of this species with vespid wasps and with a stratomyid fly are also provided. Umbonia spinosa (Fabricius, 1775) (Hemiptera: Membracidae) is reported as prey.

\section{Zusammenfassung}

Das Nistverhalten von Hoplisoides vespoides (Sмітн, 1873) wird auf Grund von Beobachtungen in SüdostBrasilien beschrieben. Bemerkungen über die Mimikry-Beziehungen dieser Art zu Faltenwespen und einer Waffenfliege werden präsentiert. Die vorliegenden Beobachtungen haben gezeigt, dass Umbonia spinosa (Fabricius, 1775) (Hemiptera: Membracidae) eine Beute von H. vespoides ist.

\section{Keywords}

Wasp, biology, reproduction, mimicry, Umbonia spinosa, Hoplitimyia mutabilis.

\section{Introduction}

Hoplisoides Gribodo is a genus of ground-nesting solitary wasps distributed in all the continents except Australia (Bohart 1997, 2000). This genus contains about 80 species, but the biology of only a few of them was studied (see Reinhard 1925a, b, Evans 1954, 1966, Powell \& Chemsak 1959, Evans \& O’Neill 2007). Hoplisoides vespoides (Smith, 1873) is distributed from Argentina to Mexico (Bohart 2000, Amarante 2002); the biology of this species is known only from the short notes by Pate (1941) and Callan (1977). In the present paper the nesting behaviour of Hoplisoides vespoides is described, based on observations carried out in southeastern Brazil. Notes on mimetic relationships of this species with vespid wasps and with a stratiomiyd fly are also provided. 


\section{Material and methods}

The study was conducted in January 2005, in a newly reclaimed area from the Lagoon of Piratininga, in the locality called Cafubá, city of Niterói, Rio de Janeiro State, southeastern Brazil. The nesting behaviour of four females was observed in detail from the early burrow excavation until the final nest closing, and about 20 other females were observed in distinct phases of the nesting cycle. Prey specimens collected from the wasps nest were measured, as follows: pronotum length (from the top of the corona to the end of the pronotum, excluding the tip of the wings), distance between umeral processes; and pronotum height (from the base of umeral process to the tip of the dorsal spine). Voucher specimens of the wasps and its preys and of the mimetic stratomyid fly were deposited in the Hymenoptera collection of the Museu Nacional - Universidade Federal do Rio de Janeiro (MNRJ).

\section{Results}

Digging behaviour and nest structure. The females nested in loose sand, the most in exposed sites; only one observed female was nesting near the base of a small plant. They dig the soil with the forelegs, throwing the sand backwards beneath the body. Apparently the mandibles are never used in the nest digging. It was not possible to determine in detail the nest architecture because the walls of the burrows collapse during the excavation, but in general lines, the nest is a strongly oblique burrow with a final cell parallel to the ground wherein the preys are stored. The sand excavated from the burrow forms a mound at the nest entrance. The females do not scatter this mound during the nest digging, but sometimes they remove lumps of sand from the portion of the mound nearer the nest entrance, apparently to avoid that the sand fall into the burrow. The depth of some nests, number of preys per nest, and the time spent in some phases of the nesting cycle are depicted in the Table I.

Temporary closing of the nest. Soon after the nest is ready, the females temporarily close its entrance. They enter the burrow headfirst, turn around inside the nest, and exit headfirst throwing sand backwards beneath the body with the forelegs, thus forming a sand plug that close the more superficial portion of the burrow. After that, sometimes, the females throw over the entrance some sand from the nest surroundings but they do not compact the sand over the nest. Then, the females leave in search for preys. Firstly, they tend to slowly fly in an upward direction, but suddenly they depart flying away more rapidly. The overall time spent in the temporary nest closing is less than one minute.

Nest provision and preys. The females store each nest cell with one or two adult females of Umbonia spinosa (FABRICIUS, 1775) (Hemiptera: Membracidae) (Fig. 1). The prey is completely and definitely paralysed by the wasp venom. Morphometric features of some preys collected from the wasp's nests are depicted in Table II.

Prey carriage and placement into the nest. After approximately 10-15 minutes absent from the nesting site, the females arrive slowly flying, carrying a prey venter to venter, held with the midlegs. They land precisely at the nest entrance; in any moment they walk on the ground carrying the prey. Apparently the females localize the nest during the slow flights over the nesting site. Then, without releasing the prey, the females open the sand plug, digging with the forelegs. In this moment the females maintain the prey held with the midlegs and sustain their own body with the hindlegs. When the females throw the sand backwards to open the plug, they move their body upward. 
Table I. Nest depth, number of preys per nest and time spent in distinct phases of the nesting cycle of Hoplisoides vespoides (nest depth in $\mathrm{cm}$; time in minutes).

\begin{tabular}{|c|c|c|c|c|c|}
\hline Nest & Nest depth & $\begin{array}{c}\text { No. of } \\
\text { preys }\end{array}$ & $\begin{array}{c}\text { Time spent in } \\
\text { nest digging }\end{array}$ & $\begin{array}{c}\text { Time spent in } \\
\text { definitive nest closing }\end{array}$ & $\begin{array}{c}\text { Total time } \\
\text { of nesting }\end{array}$ \\
\hline I & 5 & 2 & 18 & 28 & about 80 \\
\hline II & 4 & 2 & - & - & - \\
\hline III & 4.5 & 2 & - & - & - \\
\hline IV & 4.5 & 1 & - & 15 & - \\
\hline
\end{tabular}

Table II. Morphometric features of specimens of Umbonia spinosa (Hemiptera: Membracidae) collected from the nests of Hoplisoides vespoides (measurements in $\mathrm{mm}$ ).

\begin{tabular}{|c|c|c|c|}
\hline Prey & $\begin{array}{c}\text { Pronotum } \\
\text { length }\end{array}$ & $\begin{array}{c}\text { Distance between umeral } \\
\text { processes }\end{array}$ & $\begin{array}{c}\text { Pronotum } \\
\text { height }\end{array}$ \\
\hline I & 14.5 & 8 & 12.5 \\
\hline II & 14.5 & 7.5 & 12 \\
\hline III & 15 & 8 & 12.5 \\
\hline IV & 15 & 8 & 12.5 \\
\hline V & 15 & 8 & 13 \\
\hline VI & 15 & 8 & 12.5 \\
\hline VII & 14 & 7.5 & 11.5 \\
\hline VIII & 13.5 & 7.5 & 11.5 \\
\hline
\end{tabular}

Thus, the thrown sand passes beneath their body without hitting the prey. After has opened the plug, they plunge into the burrow and immediately release the prey, which remains blocking the nest entrance. Inside the nest the females turn around and, without exit from the burrow, grasp the dorsal spine of the prey with the mandibles and pull her into the nest. One observed female was not able to make the prey pass through the nest entrance after trying for about two minutes, apparently because the prey was too large. Then she, still inside the burrow, moved the prey using the mandibles, grasped one prey leg and successfully pull it into the nest. A white sausage-shaped egg was found on one of the observed prey; the position of this prey inside the nest suggests that the egg was put on the second hunted prey.

Definitive nest closure. Soon after storing the last prey into the nest, the females start to definitively close the nest opening. The behaviour is similar to when they close temporarily the nest. However, the sand is put deeper inside the burrow. Moreover, the females repeatedly enter the nest and exit throwing the sand backwards; thus the nest is almost completely filled with sand. After the burrow is levelled, the females scatter sand of the nest surroundings and of the sand mound resulted from the excavation. Then they compact the sand over the nest pounding with the tip of the gaster. While they are scattering the sand, their antennas remain downward. In a different way, when some ants approximated of one nest, the female charged against them with the antennae erected upward forming an approximately right angle with the head.

Mimicry. As its specific epithet implies, Hoplisoides vespoides has morphological features very suggestive of Vespidae mimicry, namely black-yellow striped colouration on the gaster and 

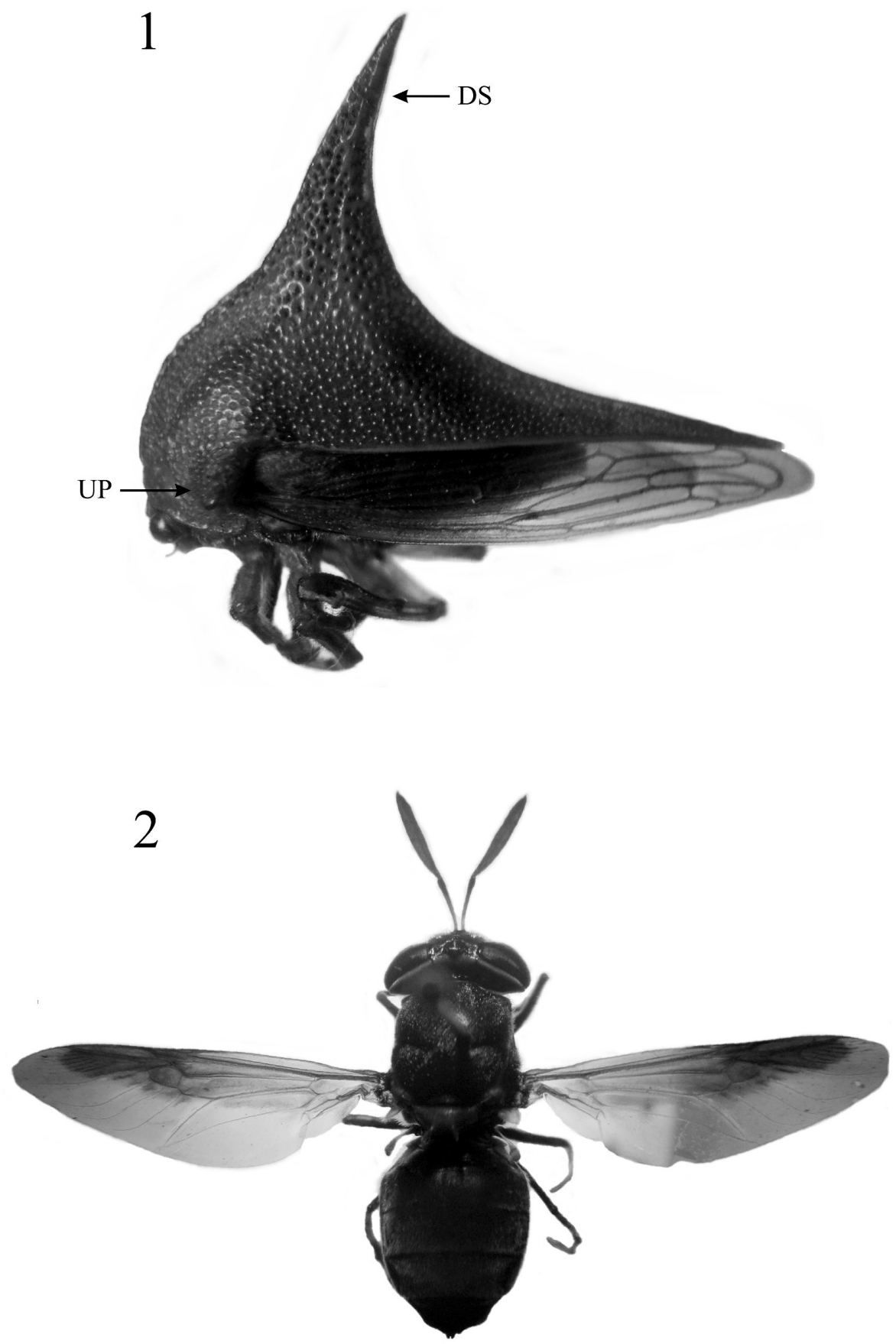

Fig. 1. Umbonia spinosa (Hemiptera: Membracidae) (lateral view). Specimen collected from a nest of Hoplisoides vespoides (DS $=$ dorsal spine; $\mathrm{UP}=$ umeral process). - Fig. 2. Hoplitimyia mutabilis (Diptera: Stratiomyidae) (dorsal view). Specimen collected on the nesting site of Hoplisoides vespoides. 
darkened forewings costal area (blackish colouration of most marginal cell and submarginal cell II, and superior portion of the submarginal cell III; brownish colouration of portions of the submarginal cell I, medial and discoidal cells). The later feature, plus the fact of the females left the wings a little open and forming an oblique angle in relation to the body when they excavate the nests, makes their wings resembling the peculiar longitudinally folded wings of vespids in resting position. It is remarkable that, a specimen of Hoplitimyia mutabilis (FABRICIUs, 1787) (Diptera: Stratiomyidae) was found resting on the ground near the nesting sites of Hoplisoides vespoides. The morphology of that fly is strongly vespid-mimic (Fig. 2) and it is very similar to Hoplisoides vespoides in features as follows: similar body size, abdomen basally constricted, darkened costal area of the wings, body in general black with yellow strips on the abdomen.

\section{Discussion}

The most of the previously studied species of Hoplisoides share behavioural features as the following: (1) nest gregariously in (2) sandy soil; (3) dig multicellular nests (4) throwing the sand backwards with forelegs; (5) transport the prey in flight (6) held with the midlegs; (7) put several small preys per nest cell; (8) close temporarily the nest entrance; (9) fly slowly when leaves or arrives at the nesting site (e.g. Reinhard 1925a, Evans 1954, Powell \& Chemsak 1959, Bohart \& Menke 1976, Callan 1977, Sanchez \& Genaro 1992, Evans \& O’Neill 2007). Although Hoplisoides vespoides shares several behavioural features with other species of the genus, it is remarkably different in nesting solitarily; in constructing unicellular nests; and in storing the nests with a smaller number of a larger prey species. Solitary nesting and construction of unicellular nest can be local ecologically-determined features. On the other hand, the use of larger preys seems to be a more stereotyped feature, probably related to the fact that Hoplisoides vespoides is one of the largest species of the genera. The use of the dorsal spine of the prey to pull her into the nest was not mentioned in other Hoplisoides species. This behaviour could partially explain the specialized use of Umbonia spinosa as prey by Hoplisoides vespoides.

Vespid-mimic morphological features were observed in some species of Hoplisoides (e.g. BOHART 2000), as well the habit of let the wings elevated during the nest excavation (SANCHEZ \& GENARO 1992). Handlirsch (1888) suggested a mimetic relation among Hoplisoides vespoides and a species of the eumenine genus Odynerus LATreille (Hymenoptera: Vespidae). Certainly, morphological and behavioural features of Hoplisoides vespoides make this species similar to several co-occurring Vespidae species common in Atlantic forest from southeastern Brazil. These vespids clearly form a Müllerian mimicry ring, of which Hoplisoides vespoides apparently is one element, even that this species is not so aggressive as usually are the vespids. Differently, Hoplitimyia mutabilis could be interpreted as a Batesian mimetic with a generalised vespid model, but at least locally Hoplisoides vespoides seems to be its model.

\section{Acknowledgement}

I thank Cinara de Andrade for the valuable help in the field work; Gabriel Mejdalani for facilitating the examination of specimens of Umbonia spinosa from the collection of the Nacional - Universidade Federal do Rio e Janeiro; Leandro Barbosa and André Cunha for identifying Hoplitimyia mutabilis. I also thank an anonymous referee for the helpful comments on the manuscript. 


\section{References}

Amarante, S. T. P. 2002: A synonymic catalog of the neotropical Crabronidae and Sphecidae (Hymenoptera: Apoidea). - Arquivos de Zoologia 37 (1): 1-139.

Bohart, R. M. 1997: A review of the genus Hoplisoides Gribodo (Hymenoptera: Sphecidae) in North America. - Proceedings of the Entomological Society of Washington 99: 645-660.

Bohart, R. M. 2000: A review of Gorytini in the Neotropical Region (Hymenoptera: Sphecidae: Bembecinae). - Contributions on Entomology, International 4 (2): 111-259.

Bohart, R. M. \& Menke, A. S. 1976: Sphecidae wasps of the world - a generic revision. - Pp. ix +695 . - Berkeley: University of California Press.

Callan, E. McC. 1977: Observations on the nesting behaviour and prey of gorytine wasps in Trinidad. - Psyche 83: 324-335.

Evans, H. E. 1954: Biological notes on Psammaecius tricolor (Cresson). - Entomological News 65: 6-11.

Evans, H. E. 1966: The comparative ethology and evolution of the sand wasps. - Pp. xvi + 526. - Cambridge: Harvard University Press.

Evans, H. E. \& O’Neill, K. M. 2007: The Sand Wasps: Behavior and Natural History. - Pp. xvii + 340. - Cambridge: Harvard University Press.

Handlirsch, A. 1888: Einige Fälle von Mimikry zwischen Hymenopteren. - Verhandlungen der kaiserlichköniglichen Zoologisch-Botanischen Gesellschaft in Wien 38: 67- 69.

Pate, V. S. L. 1941: Two new species of sphecoid wasps from Trinidad (Hymenoptera: Aculeata). - Notulae Naturae, 91: 1-8.

Powell, J. A. \& Chemsak, J. A. 1959: Some biological observations on Psammaecius adornatus (Bradley). - Pan-Pacific Entomology 35: 195-201.

Reinhard, E. G. 1925a: The wasp Hoplisus costalis, a hunter of tree-hoppers. - Journal of Washington Academy of Science 15: 107-110.

Reinhard, E. G. 1925b: The wasps Nysson hoplisivora, a parasitic relative of Hoplisus costalis. - Journal of Washington Academy of Science 15: 122-177.

Sanchez, C. S. \& Genaro, J. A. 1992: Observaciones sobre la conduta de nidificación de Hoplisoides ater y H. jaumei (Hymenoptera: Sphecidae). - Ciencias Biológicas 25: 150-154.

\section{Authors' address:}

Sandor Christiano Buys

Departamento de Entomologia, Museu Nacional

- Universidade Federal do Rio de Janeiro

Quinta da Boa Vista, São Cristóvão, 20.940-040

Rio de Janeiro, RJ, Brasil

E-mail: sbuys@biologia.ufrj.br

\section{Subject editor:}

Prof. Dr. H. H. Dathe 